\title{
The Konya earthquakes of 10-11 September 2009 and soil conditions in Konya, Central Anatolia, Turkey
}

\author{
R. Aksoy ${ }^{1}$ and A. Demiröz ${ }^{2}$ \\ ${ }^{1}$ Selçuk University, Department of Geological Engineering, 42031 Konya, Turkey \\ ${ }^{2}$ Selçuk University, Department of Civil Engineering, 42031 Konya, Turkey \\ Correspondence to: R. Aksoy (raksoy@ selcuk.edu.tr)
}

Received: 11 October 2011 - Revised: 1 December 2011 - Accepted: 21 December 2011 - Published: 10 February 2012

\begin{abstract}
Earthquakes registering magnitudes $M_{\mathrm{d}}=4.5$ and 4.7 struck the city of Konya, Central Anatolia, on 10 11 September 2009, causing very slight damages. The earthquake epicenters were located at the east of Sille District along the Konya Fault Zone, a dip-slip fault. The nature and seismicity of the fault zone indicates that it is capable of producing earthquakes of moderate magnitudes. This paper summarizes the geologic data along the fault zone and documents groundwater conditions and analyzes borehole and geotechnical data of the Konya city. The residential area of the city covers an area of approximately 1150 square kilometers and consists almost entirely of flat land except for a small part of rugged land in the southwestern corner. Groundwater and geotechnical data were collected and analyzed to evaluate the liquefaction potential of deposits under the Konya city. This preliminary investigation indicates that areas for liquefaction are generally limited to the eastern and east central parts of the city.
\end{abstract}

\section{Introduction}

The study area is located in Central Anatolia (Fig. 1). The neotectonic regime of Central Anatolia is known as the "Ova Regime" (Şengör, 1980) and "Central Anatolian neotectonic regime" (Koçyiğit et al., 2000). The extensional tectonic regime is currently active in the region (Şengör, 1980; Koçyiğit, 1984; Toprak and Göncüoğlu, 1993; Koçyiğit and Beyhan, 1998; Koçyiğit et al., 2000; Koçyiğit and Özacar, 2003). In the vicinity of Konya, late Miocene-early Pliocene extensional tectonic regime-generated faults are widespread. One of these faults is the normal slip Konya Fault Zone (Koçyiğit, 1984; Özcan et al., 1990; Aksoy and Eren, 2004).
The fault zone consists of northeast-trending fault segments along the ridge fronts bordering the western margin of the Konya depression.

The magnitude $M_{\mathrm{d}}=4.5$ and $M_{\mathrm{d}}=4.7$ earthquakes occurred in Konya city on 10-11 September 2009 at a depth of 5.0 and $5.4 \mathrm{~km}$, respectively. These earthquakes occurred on the Konya Fault Zone approximately $8 \mathrm{~km}$ northwest from downtown, a sparsely populated area in the Sille District. By 30 September, over 80 aftershocks measuring 2.5 or higher magnitude had been recorded by the Boğaziçi University Kandilli Observatory and Earthquake Research Institute (http://www.koeri.boun.edu.tr). Figure 2 shows the relationship between time and magnitude of aftershocks. Shaking associated with intensity V on the Modified Mercalli scale was recorded in Konya city and its suburbs. They were also felt in surrounding towns.

Officials in the city of Konya have reported there being no significant damage or any loss of lives during these earthquakes. However, since earthquake forces were amplified by the poor dynamic characteristics of the soil, slight damages to some buildings occurred. The main reason for the slight structural damages was due to the poor quality construction of buildings built on alluvial soils.

We conducted a field investigation in the Konya depression, especially in the western part of the city, including mapping, the documentation of soil conditions at selected sites and delineating the fault traces. Ground-water information and subsurface geotechnical data were collected and analyzed to evaluate the liquefaction potential of Quaternary sedimentary deposits. This paper summarizes the preliminary findings from this ongoing study. 


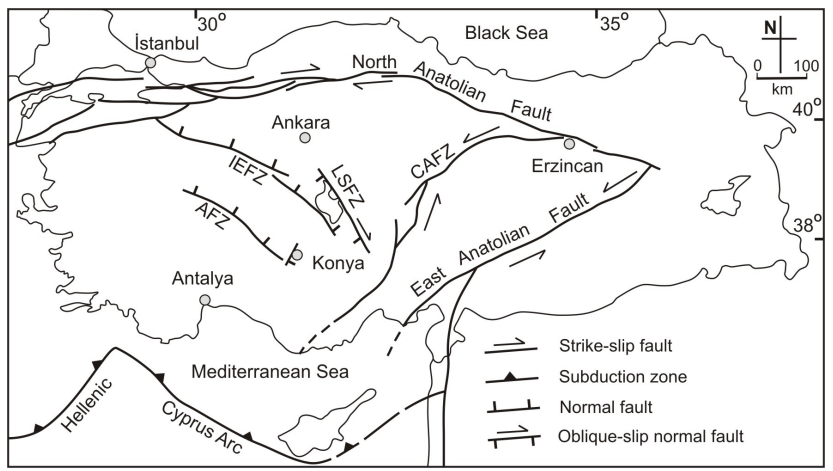

Fig. 1. Major neotectonic structure of Turkey and location of the study area (simplified after Koçyiğit and Özacar, 2003). AFZ, Akşehir Fault Zone; CAFZ, Central Anatolian Fault Zone; IEFZ, İnönü-Eskişehir Fault Zone; LSFZ, Lake Salt Fault Zone.

\section{The Konya city}

Konya is the second largest city in the Central Anatolia region of Turkey, with a population of 1003373 as of 2010 census within its administrative province on a land area of $1150 \mathrm{~km}^{2}$. The heart of the city is densely populated and includes the counties of Selçuklu, Meram and Karatay. The city lies in a plain covered by thick Plio-Quaternary alluvial and fluvial sedimentary deposits and recent alluvium. A borehole drilled through these sediments by Konya Water and Sewerage Administration did not encounter bedrock at a depth of $765 \mathrm{~m}$ (H. Kahveci, personal communication, 2010). Most of the building stock in Konya is built as multi-story reinforced concrete apartment buildings. Beside this, there are some two- and three-story masonry constructions scattered all over the city. The older one- and two-story adobe houses are mostly found in the downtown area. The city's single family housing stock mostly can be found in the southwest of the city.

\section{Physiography}

The mapped area covers the western part of Konya city and includes parts of the counties Selçuklu and Meram. The eastern part of the city contains unincorporated parts of Konya and is sparsely inhabited. Much of the city lies in flat land of the Konya depression. Elevations in the city range from about $1001 \mathrm{~m}$ at the east central part to $1140 \mathrm{~m}$ at its northern boundary.

The western part of the city is occupied by gently- to steeply-sloping ridge front. The ridge front is controlled by the northeast-southwest trending Konya fault zone. West of the Konya fault zone, rugged and mountainous terrain dominates the region. This part of the mapped area includes approximately east-west trending ridges and east-draining intervening valleys. The valleys extending from the ridge

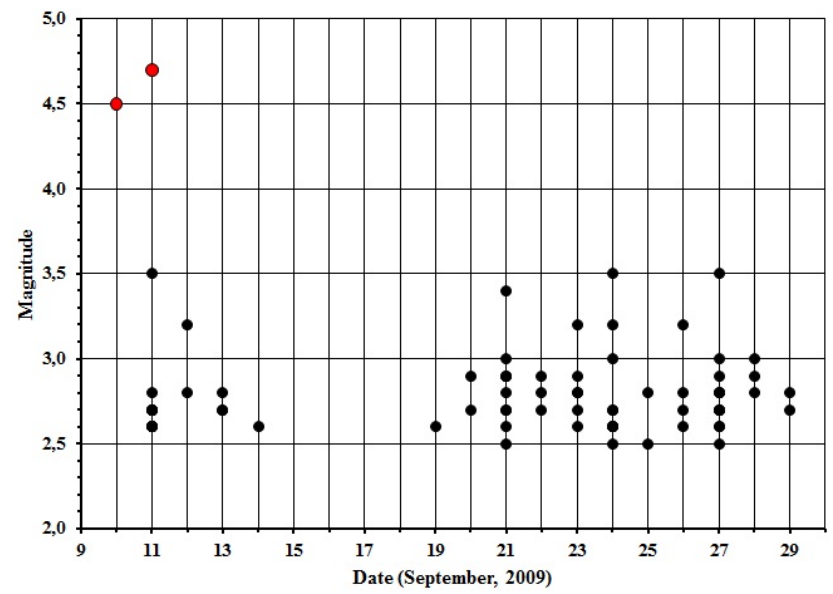

Fig. 2. History of the main shocks and aftershocks with magnitudes greater than or equal to 2.5 occurring between 9-30 September 2009 (data from Koeri, http://www.koeri.boun.edu.tr).

crests to the Konya depression become flat-bottomed alleviated valleys within the Konya plain.

\section{Geological setting}

The study area located in Central Anatolia lies on the northern margin of the Menderes-Tauride platform (Şengör, 1984). Geologic features in the region were mapped during the previous studies by Wiesner (1968), Göğer and Kiral (1969), Özcan et al. (1988, 1990) and Eren (1993). Rock units near the Konya Fault Zone were mapped in detail in this study (Fig. 3).

Rock units found in and adjacent to the fault zone include undifferentiated basement rocks of Paleozoic-Mesozoic age, the upper Cretaceous Hatip Ophiolitic Complex, the Mesozoic Çayırbağı Ophiolite, the upper Miocene-lower Pliocene fluviolacustrine sediments and volcanic rocks, the upper Pliocene-Quaternary older alluvium and as well as younger alluvium. The low grade Paleozoic and Mesozoic metamorphic rocks of the region can be regarded as parts of the Afyon-Bolkardağ 1 Zone of Okay (1986). The region had distinctive stratigraphic, metamorphic, deformational features and an important Alpine orogenic history.

Metacarbonates form the base of the metamorphics and consist of marble, dolomite marble and dolomitic limestone. These pass up into a metaclastic unit composed of phyllite, graphitic schist, calcschist, metasandstone, metaconglomerate, metachert and metacarbonate blocks. These rocks are intruded by metamagmatics. All of these rocks are unconformably overlain by a continuous, well-developed transgressive sedimentary sequence extending from the upper Permian to Cretaceous (Göğer and Kıral, 1969; Görmüş, 1984; Özcan et al., 1988; Eren, 1993). This succession starts with phyllite, metasandstone and metaconglomerate which 


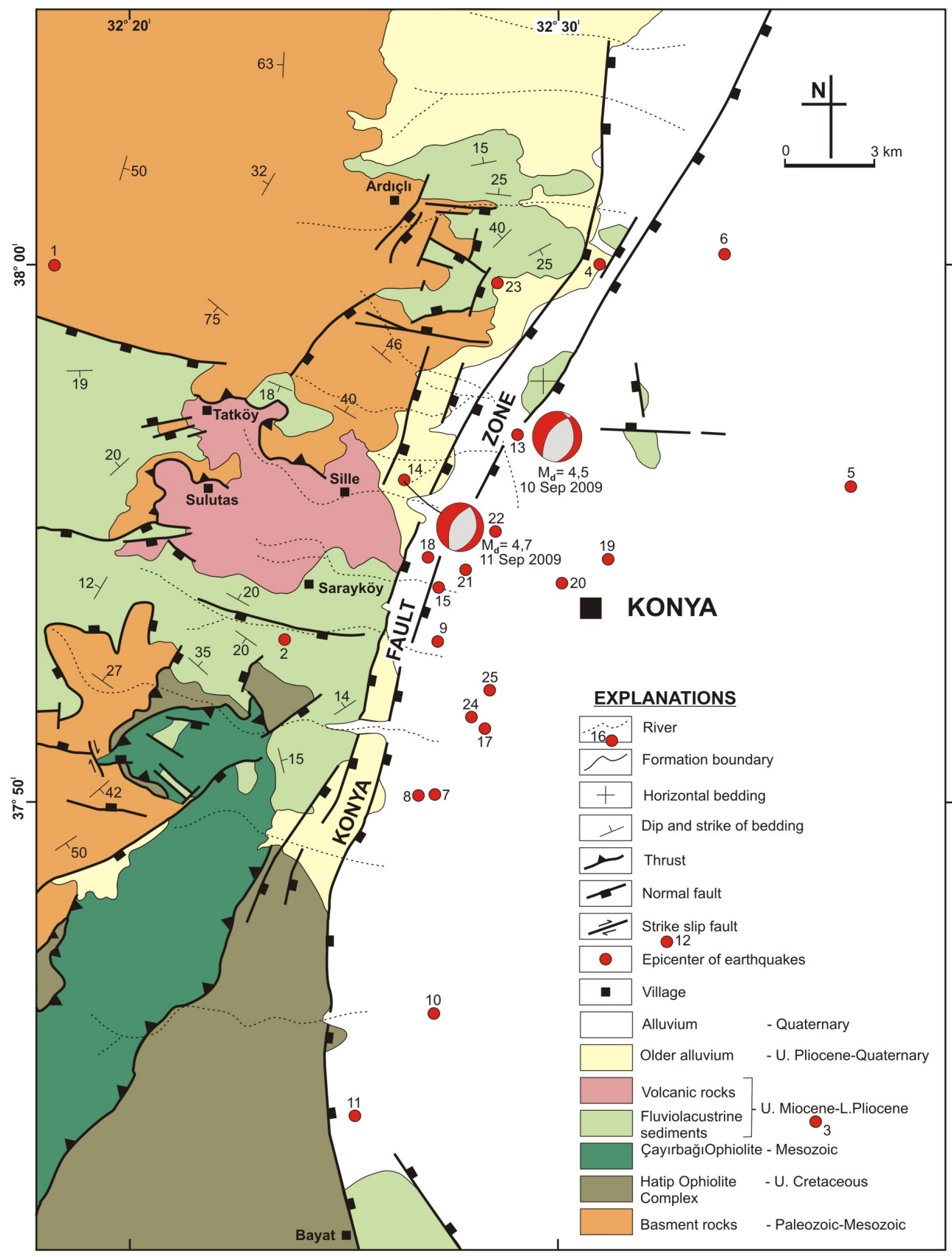

Fig. 3. Geologic map of the Konya Fault Zone (modified from Aksoy and Eren, 2004; with added new data). Map shows fault plane solution of two earthquakes (data from Italian INGV). Numbers 1 through 25 indicate epicenters of earthquakes.

is overlain by intercalation of phyllite, metasandstone, calcschist, and metacarbonate, followed by dolomite, marble, crystallized limestone and dolomitic limestone and ends with a sequence of well-bedded metachert, metacarbonate and metasandstone. These rock units are tectonically overlain by the Hatip Ophiolitic Complex (Özcan et al., 1988) occurring on the southern termination of the fault zone. It is composed of radiolarite, serpentinite, harzburgite, gabbro and diabase with limestone blocks. The Çayırbağı Ophiolite was obducted over the Hatip Ophiolitic Complex during the Maastrichtian-early Paleocene (Özcan et al., 1988).

The upper Miocene-lower Pliocene fluviolacustrine sediments, volcanoclastics and volcanic rocks unconformably cover all the older units. During this time these sedimentary and volcanic rocks covered large areas in western Konya (Fig. 3). That was also the time of initiation of extensional tectonic regime in Central Anatolia (Şengör, 1980; Koçyiğit, 1984; Toprak and Göncüoğlu, 1993; Koçyiğit and Beyhan, 
1998; Koçyiğit et al., 2000) and the normal slip Konya fault Zone (Aksoy and Eren, 2004). All these units are unconformably overlain by the upper Pliocene-Quaternary alluvial complex and alluvium covering the Konya depression.

\section{The Konya fault zone}

The Konya fault zone comprises a set of northeast trending subparallel breaks along the eastern front of the foothills bordering the west side of the Konya plain. It extends for nearly $65 \mathrm{~km}$ from Hatunsaray south to its northern termination north of Konya city (Fig. 3), and may extend in either direction beyond these limits. It has been delineated by Koçyiğit (1984), Özcan et al. (1990) and Koçyiğit et al. (2000) and well described by Aksoy and Eren (2004). Fault geometry and complexity changes towards the south. These changes include a gradual $35^{\circ}$ bend to the south from about $\mathrm{N} 15^{\circ} \mathrm{E}$ along the northeastern section to $\mathrm{N}-\mathrm{S}$ in the central section and $\mathrm{N} 20^{\circ} \mathrm{W}$ in the southern section. It consists of a $5 \mathrm{~km}$ wide, rather long, eastwardly facing step-like normal faults. Movement along the fault zone is predominantly dip-slip, with a minor dextral strike-slip component. In addition, thrusting of east side over the west side was observed in a road-cut exposure at the southwestern part of the chromium magnesite facility. In the footwall area, the upper Miocene-lower Pliocene fluviolacustrine sediments have been faulted, uplifted and tilted as fault terraces lying at different elevations up to $520 \mathrm{~m}$ above the present day elevation $(1040 \mathrm{~m})$ of the Konya alluvial plain in the hanging wall of the fault zone (Fig. 3). A well drilled by Konya Water and Sewerage Administration through the Quaternary alluvium in the hanging wall of the Konya fault zone did not encounter the bottom of the same unit at depth of $765 \mathrm{~m}$ below the present-day elevation of the Konya depression (H. Kahveci, personal communication, 2010). This suggests that the vertical throw on the fault zone is about $1285 \mathrm{~m}$. Aksoy and Eren (2004) determined a minimum slip rate of $0.25-0.6 \mathrm{~mm} \mathrm{yr}^{-1}$ based on correlating offset fluviolacustrin sediments since the late Miocene.

The most common young-looking fault features along the fault zone are fault scarps, deflected stream courses, elongate ridges, notches and lines of springs. Nevertheless, these geomorphic evidences are not clear everywhere because of intense urban development and lack of exposures. Most of these features are clearly visible in the eastern part of the Sille district and in the southern part of the fault zone. A road-cut exposure in the southern part of the fault zone demonstrates recurrent Quaternary faulting. Here, Aksoy and Eren (2004) documented three undated seismic events.

There is no historical record of surface faulting associated with the fault zone, nor is there a record of earthquakes to produce surface faulting. The Konya fault zone is active and has the capacity to produce small to moderate earthquakes. The seismicity of the fault zone for the period of 1900-2009 is shown in Fig. 3 and Table 1. During this period, 25 seismic events $M \geq 3$ occurred in the area. It is evident from this figure that earthquake epicenters are concentrated along the Konya fault zone. Beside this, all these seismic events are shallow-focus earthquakes.

\section{Groundwater}

Groundwater is the main source of water in the Konya closed groundwater subbasin that covers about $1050 \mathrm{~km}^{2}$. A continuous increase in the demand for groundwater resources in recent years has resulted in groundwater overdraft. This continuous increase in water use has resulted gradually in water table drop and land subsidence.

A ground-water flow model of the Konya subbasin was developed by the Konya Water and Sewerage Administration (KOSKI) in order to better understand the regional groundwater flow system and assess future groundwater conditions. Source of water to the regional groundwater flow system is natural recharge. Most natural recharge occurs through infiltration of rain.

The basin of Konya city is filled with consolidated fluviolacustrin sediments and a mixture of unconsolidated alluvial deposits of the late Miocene-early Pliocene and Quaternary age. Generally, coarse grained sediments occur in the upper alluvial fan areas along the northern and western part of the basin, along mountain front, while thick silt/clay units interbedded with sand/gravel units are found towards the interior of the basin. These basin-fill sediments form a set of aquifer systems that have been the primary sources of water supplies for public, industry and agriculture. The northern and western areas of the Konya closed basin are recharge areas. The hydrogeology of the basin has been investigated by the State water works (DSI) (1984) and Bulduk (2009).

Groundwater elevations for spring 2009 were contoured (Bulduk, 2009). This map delineates that the groundwater typically flows in the general direction of ground surface topography, from west to east towards the interior of the Konya subbasin (Fig. 4). The largest source of discharge from the groundwater flow system in the basin is pumpage. Pumpage has caused water-levels to decline year after year. The intense pumpage in some local areas has caused change in the direction of ground-water flow. Since about 1967, water levels have declined more than $30 \mathrm{~m}$. Depth to water level was measured for 83 wells in this basin in 2009 and varies 40$50 \mathrm{~m}$ in the west to $3-10 \mathrm{~m}$ in the east central portion of the subbasin.

Liquefaction occurs in loose, granular soils in the presence of ground acceleration induced by earthquakes. When liquefaction occurs, soils lose shear strength. Therefore, saturation increases the earthquake-induced liquefaction (Youd, 1973). Bott (2006) stated that liquefaction might occur when depth to the saturated soil is less than $15 \mathrm{~m}$. In accordance with this, we evaluated the liquefaction susceptibility for the city of Konya. 
Table 1. List of earthquakes occurred around Konya. Data obtained from Boğaziçi University Kandilli Observatory and Earthquake Research Institute (Koeri: http://www.koeri.boun.edu.tr).

\begin{tabular}{rccrrr}
\hline No & $\begin{array}{c}\text { Longitude } \\
(\mathrm{X})\end{array}$ & $\begin{array}{c}\text { Latitude } \\
(\mathrm{Y})\end{array}$ & Date & $\begin{array}{r}\text { Depth } \\
(\mathrm{km})\end{array}$ & Magnitude \\
\hline 1 & 32.30 & 38.00 & 25 Sep 1965 & 0 & 0.0 \\
2 & 32.38 & 37.88 & 6 Mar 2000 & 32 & 3.5 \\
3 & 32.61 & 37.74 & 28 Mar 2000 & 14.1 & 3.6 \\
4 & 32.55 & 37.98 & 6 Mar 2004 & 3 & 3.0 \\
5 & 32.63 & 37.93 & 20 Apr 2004 & 8 & 3.1 \\
6 & 32.57 & 38.12 & 22 Aug 2004 & 2 & 3.1 \\
7 & 32.46 & 37.86 & 14 May 2005 & 5 & 3.2 \\
8 & 32.45 & 37.86 & 14 May 2005 & 5 & 3.3 \\
9 & 32.45 & 37.89 & 28 May 2005 & 23 & 3.3 \\
10 & 32.50 & 37.45 & 10 Mar 2007 & 14 & 3.5 \\
11 & 32.42 & 37.74 & 1 May 2007 & 5 & 3.1 \\
12 & 32.54 & 37.79 & 22 Oct 2007 & 1 & 3.2 \\
13 & 32.48 & 37.95 & 10 Sep 2009 & 5 & 4.5 \\
14 & 32.43 & 37.93 & 11 Sep 2009 & 5.4 & 4.7 \\
15 & 32.45 & 37.89 & 11 Sep 2009 & 6.3 & 3.5 \\
16 & 32.52 & 37.85 & 12 Sep 2009 & 5 & 3.2 \\
17 & 32.47 & 37.85 & 21 Sep 2009 & 6.7 & 3.0 \\
18 & 32.47 & 37.91 & 23 Sep 2009 & 5 & 3.2 \\
19 & 32.52 & 37.90 & 24 Sep 2009 & 4.1 & 3.2 \\
20 & 32.51 & 37.90 & 24 Sep 2009 & 4.5 & 3.5 \\
21 & 32.46 & 37.91 & 24 Sep 2009 & 5 & 3.0 \\
22 & 32.46 & 37.90 & 26 Sep 2009 & 5.3 & 3.2 \\
23 & 32.46 & 37.98 & 27 Sep 2009 & 4.9 & 3.0 \\
24 & 32.47 & 37.86 & 27 Sep 2009 & 6.4 & 3.5 \\
25 & 32.48 & 37.87 & 28 Sep 2009 & 6.4 & 3.0 \\
\hline
\end{tabular}

\section{Soil characterization in Konya}

Potentially liquefiable soils generally are restricted to areas covered by Quaternary alluvial and fluvial deposits. Soils containing saturated, loose sandy and silty deposits are most liable to liquefaction. Soil profiles and test results obtained from geotechnical borehole logs supply important information about subsurface geology, ground-water level and engineering properties of sedimentary deposits.

Areas generally underlain by loose, water-saturated, granular sediment within $12-15 \mathrm{~m}$ of ground surface are sensitive to liquefaction (Bott, 2006). In order to outline the locations most susceptible to liquefaction in the city of Konya, 14 soil borings $10-22 \mathrm{~m}$ deep with closely spaced standard penetration tests (SPT) were drilled to investigate the subsurface conditions during the years 2010 and 2011. Beside this, geotechnical borings prepared and compiled by Konya Metropolitan Municipality and private engineering firms were also evaluated.

Borehole logs were obtained for the western part of the city along the Konya Fault Zone on the alluvial fans upon which part of the Selçuklu and Meram districts in Konya were built. The materials here are generally described as moderately to densely gravelly and silty sand. Minimum and maximum SPT N-values varied from 12 to 100 . Minimum values were between 12 and 35. At the northern side of the city in the Yazır District, near surface alluvium is described as gravelly, bouldery sand interbedded with caliche, slight to moderately compact. Here, SPT N-values in the alluvium range from 19 to 100 , with low values 19 to 35 . The low values probably represent the consistency of the silty and sandy material and high values represent impact on boulders and pebbles within the sedimentary deposits. Close to the Afyon Highway in the Selçuklu District and in the city center, deposits are characterized by moderately dense sandy, gravely and silty clay. At depths greater than about $7 \mathrm{~m}$, the deposits contain interbedded sand, silty and gravely sand. Along this line in the subbasin, Afyon Highway-Alaeddin Hill, SPT N-values range from 6 to 64, and is generally between 6 and 17. Along this line, only in one geotechnical borehole was groundwater level encountered at $11.00 \mathrm{~m}$. However, the depth of groundwater based on the measurements in the water wells (Bulduk, 2009) at above mentioned sites ranges between 17 and $48 \mathrm{~m}$. At the eastern part of the city, vicinity of the Ankara and Adana Highways and eastern part of the Mevlana Museum, borehole logs describe moderately dense silty, sandy and gravely clay, silty and sandy gravel with blow counts ranging between 2 and 61, averaging 


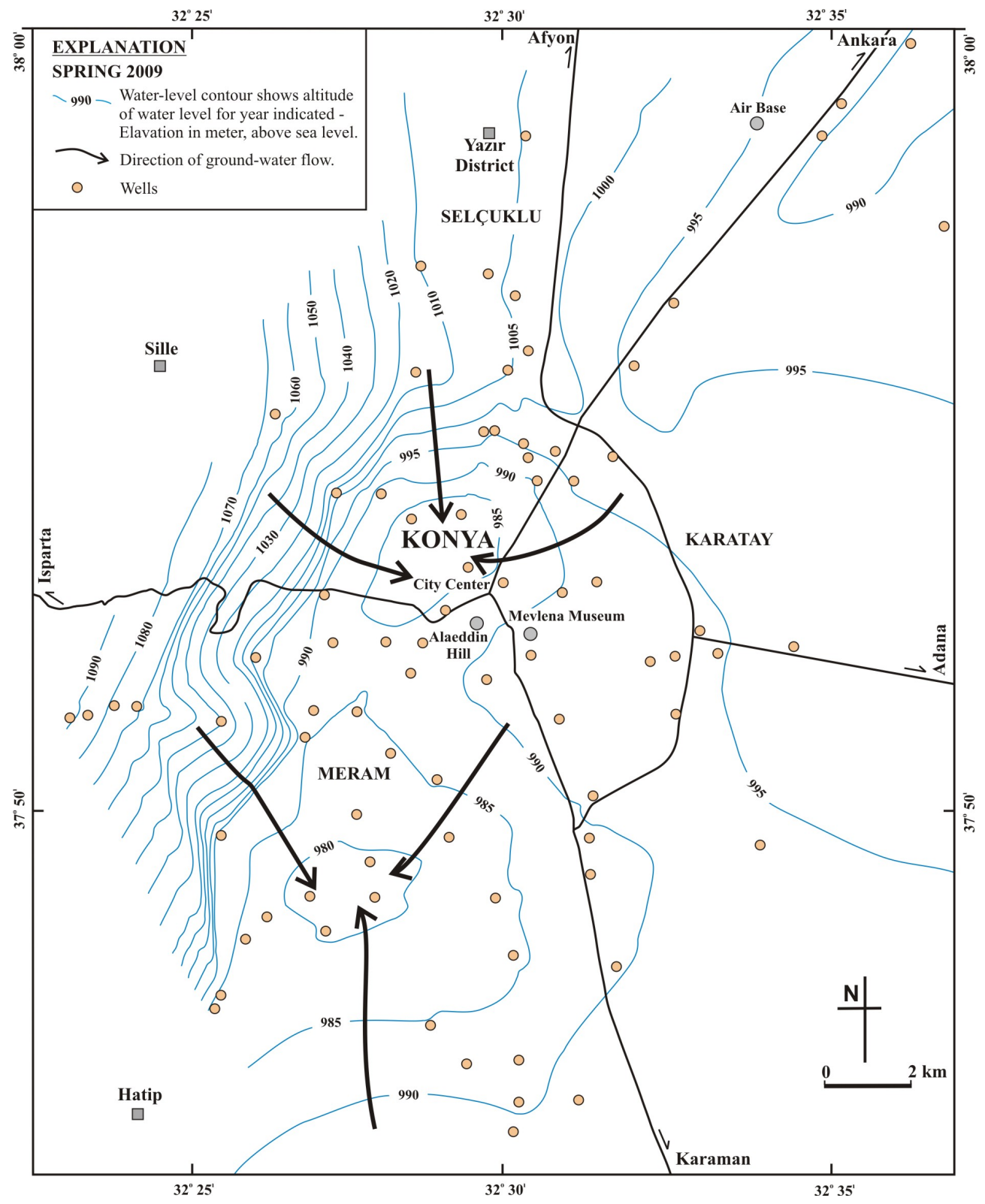

Fig. 4. Ground water table map of the Konya sub-basin (modified from Bulduk, 2009).

15. Some boreholes in the eastern part of the airbase, however, describe moderately dense silty, gravely clay interbedded with sandy gravel. The thickness of this stratum ranges from 0.5 to $4 \mathrm{~m}$. At this level, SPT N-values reach up to 89, probably representing impact on gravels. Depths to groundwater obtained from geotechnical boreholes in the eastern part of the city range from 5.50 to $10.50 \mathrm{~m}$ (Table 2). These values appear to be fairly consistent with the groundwater elevation contours, as shown on Fig. 4. Generally, the available data suggest that the grain size of the sediments progressively decreases from west to east. Geotechnical borehole logs and SPT values provided valuable information on litho- logic and engineering characteristics of sedimentary deposits in the Konya sub-basin. General geotechnical characteristics and liquefaction susceptibility of Quaternary sedimentary deposits in the Konya depression, acquired from borehole logs, are summarized in Table 2. A total of 40 borings were evaluated for liquefaction potential. The locations of drilled and collected geotechnical boreholes are shown on Fig. 5. The majority of the borings have low liquefaction potential. The consequences of liquefaction susceptibility based on SPT $\mathrm{N}$-values, material type and ground water depth are evaluated to map the liquefaction potential areas (Fig. 5). Areas with very low and low liquefaction potential are located in 
Table 2. General geotechnical characteristics and liquefaction susceptibility (LS) of Quaternary geological units in the Konya sub-basin ((1) based on the procedure Hunt, 1984). Comparative liquefaction susceptibility of units is a function of material type, SPT N-values and ground water $(\mathrm{GW})$ depth in that unit. M: moderate, L: low, and VL: very low to none.

\begin{tabular}{|c|c|c|c|c|c|c|c|c|}
\hline \multirow{2}{*}{ Profile } & \multirow{2}{*}{$\begin{array}{l}\text { Material } \\
\text { Type }\end{array}$} & \multirow{2}{*}{$\begin{array}{l}\text { Consistency } \\
\text { (1) }\end{array}$} & \multicolumn{4}{|c|}{ SPT } & \multirow{2}{*}{$\begin{array}{l}\text { Depth to } \\
\text { GW (m) }\end{array}$} & \multirow{2}{*}{ LS } \\
\hline & & & $\begin{array}{r}\text { No. of } \\
\text { Tests }\end{array}$ & Mean & Min. & Max. & & \\
\hline B1 & Gravely sand & Very dense & 6 & 75.50 & 35 & 100 & & VL \\
\hline $\mathrm{B} 2$ & Gravely sand & Very dense & 13 & 56.23 & 24 & 100 & & VL \\
\hline B3 & Gravely, sandy clay with caliche & Very dense & 6 & 60.33 & 19 & 100 & & VL \\
\hline B4 & Gravely, silty sand; sandy, silty clay & Very dense & 6 & 56.50 & 20 & 100 & & VL \\
\hline B5 & Gravely, silty clay & Dense & 6 & 34.50 & 19 & 70 & & VL \\
\hline B6 & Silty, gravely clay; gravely clay & Mod. dense & 8 & 21.50 & 6 & 76 & 10.50 & $\mathrm{~L}$ \\
\hline B7 & Silty clay; silty gravel with caliche & Dense & 9 & 34.55 & 8 & 89 & 8.30 & M \\
\hline B8 & Silty, sandy clay & Mod. dense & 10 & 12.60 & 5 & 21 & 7.00 & $\mathrm{M}$ \\
\hline B9 & Silty, sandy clay & Mod. dense & 10 & 20.30 & 6 & 59 & 9.00 & $\mathrm{M}$ \\
\hline $\mathrm{B} 10$ & Silty clay; clayey, silty, sandy gravel & Dense & 6 & 36.00 & 17 & 61 & 8.50 & $\mathrm{M}$ \\
\hline B11 & Gravely, silty clay & Dense & 6 & 43.83 & 14 & 64 & & VL \\
\hline B12 & Gravely, sandy clay & Very dense & 6 & 54.60 & 20 & 100 & & VL \\
\hline B13 & Gravely, sandy clay; sand; clay & Mod. dense & 6 & 24.66 & 14 & 54 & & VL \\
\hline B14 & Gravely, silty sand & Dense & 6 & 34.50 & 21 & 53 & & VL \\
\hline B15 & Silty sand; gravel; gravely, sandy clay & Very dense & 6 & 56.33 & 26 & 100 & & VL \\
\hline B16 & Gravely, silty sand & Very dense & 6 & 54.83 & 25 & 84 & & VL \\
\hline B17 & Silty sand; clay; clayey, silty sand & Very dense & 8 & 62.12 & 33 & 80 & & VL \\
\hline B18 & Silty clay; silty, clayey sand; silty clay & Dense & 10 & 39.90 & 15 & 61 & 11.00 & $\mathrm{M}$ \\
\hline B19 & Gravely, sandy clay & Mod. dense & 10 & 12.10 & 6 & 17 & 10.40 & $\mathrm{M}$ \\
\hline B20 & Silty clay; sand-gravel; silty clay & Loose & 10 & 6.80 & 3 & 10 & 12.30 & $\mathrm{~L}$ \\
\hline B21 & Silty, sandy clay; silty clay; sandy clay & Mod. dense & 10 & 15.30 & 7 & 41 & 11.50 & $\mathrm{~L}$ \\
\hline $\mathrm{B} 22$ & Silty, sandy clay & Loose & 9 & 9.70 & 2 & 24 & 5.50 & M \\
\hline $\mathrm{B} 23$ & Silty, sandy clay & Loose & 10 & 5.70 & 2 & 11 & 6.00 & M \\
\hline B24 & Silty clay, sand, clay & Mod. dense & 13 & 16.53 & 6 & 27 & 8.50 & M \\
\hline $\mathrm{B} 25$ & Silty clay & Loose & 13 & 9.15 & 3 & 23 & 6.30 & $\mathrm{M}$ \\
\hline B26 & Silty, sandy clay & Mod. dense & 13 & 16.53 & 6 & 27 & 8.50 & M \\
\hline B27 & Clay; sand & Mod. dense & 5 & 19.20 & 16 & 38 & & VL \\
\hline B28 & Gravely, silty clay; sand; silty clay & Mod. dense & 6 & 22.30 & 10 & 37 & & VL \\
\hline B29 & Silty clay; sand; silty-gravely clay; sand & Mod. dense & 10 & 20.10 & 10 & 44 & 15.20 & $\mathrm{~L}$ \\
\hline B30 & Clay; gravely, clayey sand & Very dense & 10 & 52.90 & 30 & 100 & & VL \\
\hline B31 & Gravely, sandy, silty clay; sand & Mod. dense & 5 & 29.00 & 13 & 54 & & VL \\
\hline B32 & Clay; silty sand & Dense & 6 & 33.50 & 15 & 44 & & VL \\
\hline B33 & Gravely, silty sand; silty clay & Dense & 6 & 39.50 & 16 & 67 & & VL \\
\hline B34 & Silty sand; sand & Dense & 5 & 36.20 & 19 & 60 & & VL \\
\hline B35 & Clay; silty, clayey sand; clay & Very dense & 6 & 52.16 & 12 & 96 & & VL \\
\hline B36 & Sandy, silty clay; silty gravel; clay & Very dense & 10 & 59.75 & 35 & 100 & & VL \\
\hline B37 & Clay; sand; silty clay; silty sand; clay & Mod. dense & 10 & 27.80 & 13 & 72 & & VL \\
\hline B38 & Sandy clay, sand, sandy-gravely clay & Dense & 10 & 59.50 & 26 & 100 & 12.20 & $\mathrm{~L}$ \\
\hline B39 & Silty, gravely clay; sand; clay; sand & Mod. dense & 6 & 19.67 & 9 & 62 & & VL \\
\hline B40 & Silty, sandy, gravely clay & Mod. dense & 10 & 17.40 & 10 & 52 & 9.50 & M \\
\hline
\end{tabular}

the west, central and southeastern parts of the city. Areas with moderate liquefaction potential are mainly located in the east and east central regions of the city (Fig. 5). A small area near the present stream channel of Meram-Dere may also be moderately susceptible to liquefaction because this area contains loose, recently deposited sediments and shallow groundwater. Liquefaction may occur in water-saturated sandy and silty soils within the upper $12-15 \mathrm{~m}$ of the ground surface during moderately to great earthquakes. Geological and groundwater conditions susceptible to liquefaction exist in eastern and east central parts of Konya city. Furthermore, the probability for moderate ground shaking is high due to some nearby active faults. 


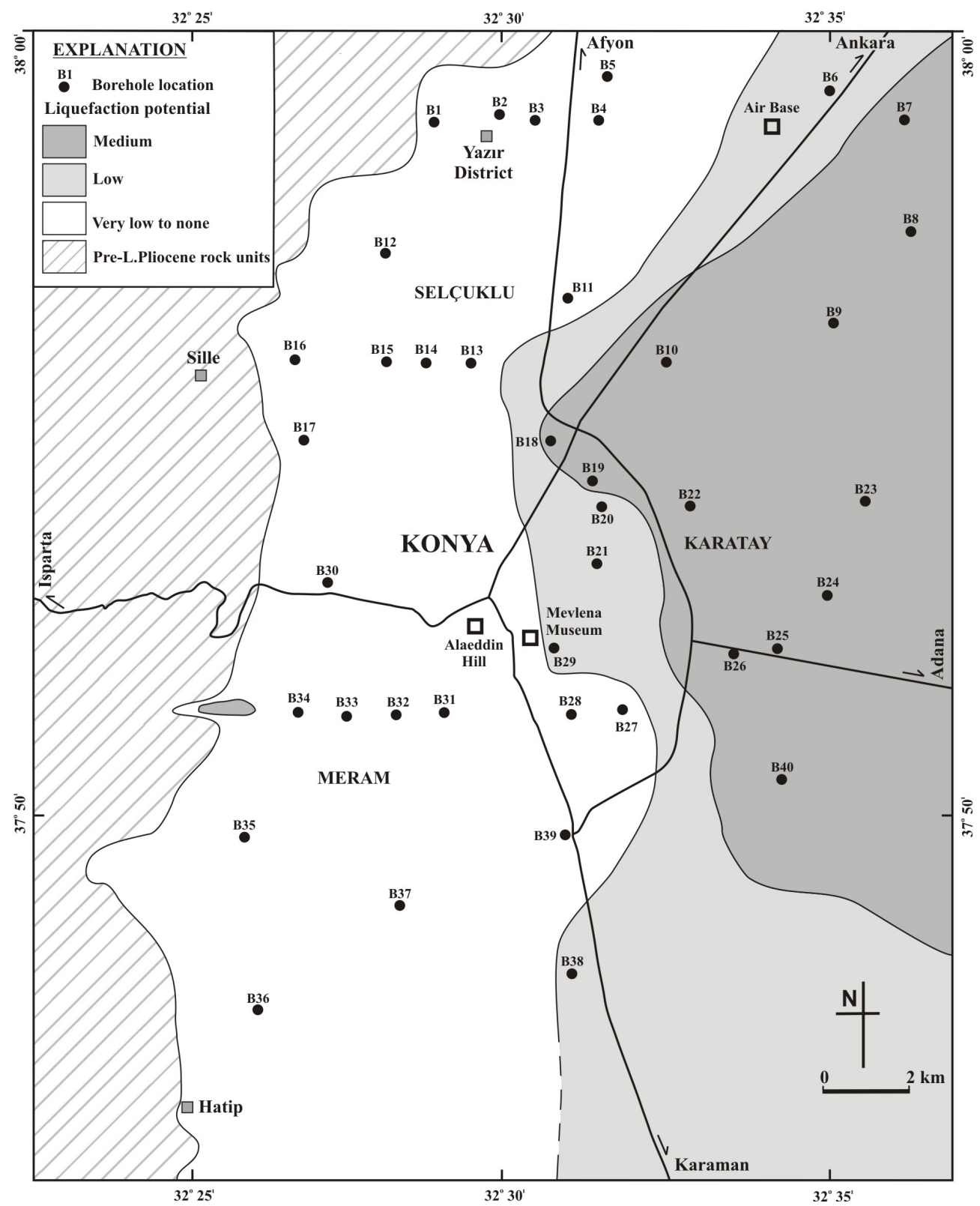

Fig. 5. Liquefaction potential map of the Konya city.

Although the 2009 Konya earthquakes were small earthquakes with magnitudes $M_{\mathrm{d}}=4.5$ and 4.7, they caused slight damages to some adobe houses and reinforced concrete structures. Considering the capacity of the Konya fault zone and nearby active faults to produce moderate earthquakes, the construction practices in Konya have to be reconsidered.

\section{Conclusions}

The Konya fault zone is one of the seismically active zones in the Central Anatolia extensional area. It is a NE-SW trending, east-dipping normal slip fault. Slickensides on the fault planes, scarps of various heights, elongate ridges and faulted Quaternary deposits along the fault are distinctive surface evidence for normal slip faulting.

The Konya fault zone separates mountainous area to the west from the Konya depression to the east. Along most of its course, fault zone juxtaposes pre-early Pliocene basement and volcano sedimentary units in the footwall with late 
Pliocene-Quaternary alluvial complex and alluvium in the hanging wall. It displays east facing step-like synthetic normal faults. Considering the geological and geomorphological field evidence and seismicity, the Konya fault zone is considered as being capable of producing earthquakes of moderate magnitudes.

Subsurface investigations indicated that the thickness and the lithology of Quaternary sedimentary deposits vary considerably throughout the Konya basin. Coarse grained bouldery, gravely and sandy sediments occur in the upper alluvial fan areas along the northern and western part of the basin. However, fine grained sand, silt and clay deposits interbedded with sand/gravel deposits are found toward the interior and eastern part of the basin. Mapping the groundwater level data delineated that groundwater in the basin moves from the mountainous terrain recharge areas toward the east to the discharge areas. Depth to ground water for 83 wells varies from $40-50 \mathrm{~m}$ in the west to $3-10 \mathrm{~m}$ in the east central of the city. Generally, water levels have begun to decline significantly in the basin since 1967. Based on preliminary assessments from site investigations, SPT N-values, ground water and geotechnical borehole data, areas susceptible to liquefaction potential were evaluated. Areas with very low and low liquefaction potential are located in the west, central and southeastern parts of the city. Areas with moderate liquefaction potential are mainly located in the east and east central regions of the city.

Acknowledgements. We are grateful to Metin Tekdere of the Konya Metropolitan Municipality for providing some of the borehole and geotechnical data. We thank Research Assistant İsmail Ince from Geological Engineering Department of Selçuk University for computer preparation of figures. We also thank reviewers for their helpful comments and remarks, which improved the paper.

Edited by: M. E. Contadakis

Reviewed by: O. Günaydin and two other anonymous referees

\section{References}

Aksoy, R. and Eren, Y.: The Konya fault zone, Journal of Faculty of Engineering and Architecture at Selcuk University, 19, 49-60, 2004.

Bott, J. D. J.: Seismic hazard zone report for the Mt. Sizer 7.5minute quadrangle, Santa Clara County, California, Section-1, Department of Conservation, California Geological Survey, report 118, 3-19, 2006.

Bulduk, A.: Research report for groundwater of Konya center and spring water of central towns, Konya Metropolitan Municipality, Water and Sewerage Administration, 68 pp., Konya, 2009 (in Turkish).
Eren, Y.: The geology of the Eldeş-Derbent-tepeköy-Söğütözü (Konya) region, Unpublished $\mathrm{PhD}$ thesis, Selcuk University, Konya, 224 pp., 1993 (in Turkish with English abstract).

Göğer, E. and Kıral, K.: Geology of the Kizılören region, Mineral Research and Exploration Institute of Turkey (MTA) Report No: 5204, Ankara, 1969 (in Turkish).

Görmüş, M.: Geological investigation in the vicinity of Kızılören (Konya), Unpublished MSc thesis, Selcuk University, Konya, 67 pp., 1984 (in Turkish with English abstract).

Hunt, R. E.: Geotechnical Engineering Investigation Manual, McGraw Hill Book Co, New York, NY, 8-76, 1984.

Koçyiğit, A.: Intra plate neotectonic development in southwestern Turkey and adjacent areas, Geological Society of Turkey Bulletin, 27, 1-6, 1984 (in Turkish with English abstract).

Koçyiğit, A. and Beyhan, A.: A new intracontinental transcurrent structure, the Central Anatolian fault zone, Turkey, Tectonophysics, 284, 317-336, 1998.

Koçyiğit, A. and Özacar, A. A.: Extensional neotectonic regime through the NE edge of the Isparta Angle, SW Turkey: new field and seismic data, Turkish Journal of earth Scieneces, 12, 67-90, 2003.

Koçyiğit, A., Ünay, E., and Saraç, G.: Episodic graben formation and extensional neotectonic regime in west central Anatolia and Isparta Angle; a case study in the Akşehir-Afyon graben, Turkey, in: Tectonics and magmatism in Turkey and surrounding area, edited by: Bozkurt, E., Winchester, J. A., and Piper, J. D. A., Geological Society, London, Special Publication, 173, 405-421, 2000.

Okay, A.: High pressure/low temperature metamorphic rocks of Turkey: In blueschists and eclogites, Geol. Soc. Am. Memorial, 164, 338-348, 1986.

Özcan, A., Göncüoğlu, M. C., Turhan, N., Uysal, Ş., Şentürk, K., and Işık, A.: Late Paleozoic evolution of the Kütahya-Bolkardağı belt, METU J. Pure Appl. Sci., 21, 211-220, 1988.

Özcan, A., Göncüoğlu, M. C., Turhan, N., Uysal, Ş., Şentürk, K., and Işık, A.: Geology of the basement rocks of the KonyaKadınhanı-Ilgın region, Mineral Research and Exploration Institute of Turkey (MTA), Report No: 9535, Ankara, 1990 (in Turkish).

State Water Works (DSI): Report for drinking and industrial water supply and its distribution network of the Konya City, 250 pp., Ankara, 1984 (in Turkish).

Şengör, A. M. C.: Principles of neotectonis of Turkey, Geological Society of Turkey conference series 2, 40 pp., 1980 (in Turkish with English abstract).

Şengör, A. M. C.: The Cimmeride orogenic system and the tectonics of Eurasia, Geol. Soc. Am. Special Paper, 195, 74 pp., 1984.

Toprak, V. and Göncüoğlu, M. C.:Tectonic control on the development of the Neogene-Quaternary central Anatolian volcanic province, Turkey, Geol. J., 28, 357-369, 1993.

Wiesner, K.: Konya mercury deposits and investigation on them, Mineral Research and Exploration Institute of Turkey (MTA), 70, 178-213, 1968 (in Turkish).

Youd, T. L.: Liquefaction, flow and associated ground failure, US Geological Survey Circular, 688, 12 pp., 1973. 